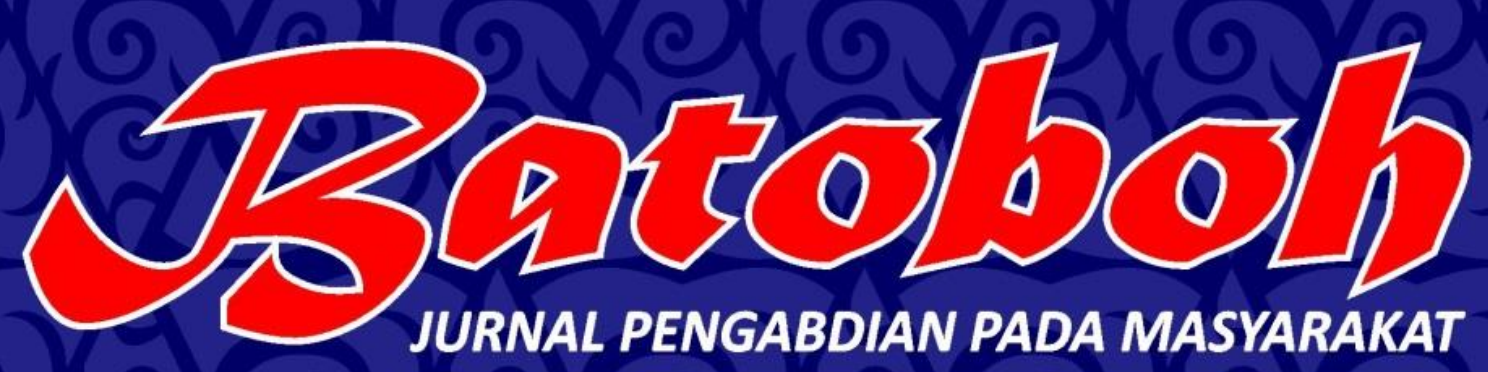

ISSN: 2548-5458

Volume 1

Nomor 2

JURNAL PENGABDIAN PADA MASYARAKAT

Oktober 2016

hlm. 131-266

Yusfil, Zulkifli, Erlinda

PENERAPAN TEKNOLOGI SENI PADA SANGGAR SENI TRADISIONAL

DI KABUPATEN PESISIR SELATAN SUMATERA BARAT

Asril

PELATIHAN LAGU SIONTONG TABANG, KURETA MANDAKI, DAN OYAK TABUIK

PADA GRUP GANDANG TASA ANAK-ANAK, SANGGAR ANAK NAGARI DESA SUNGAI PASAK, KOTA PARIAMAN

Nofrial, Wahyono, Riski Rahmat Kurniawan Dan Alek Hengki Ziora

PEMANFAATAN SERBUK GERGAJI MENJADI PRODUK KERAJINAN DI WAN PERABOT,

TARANTANG KECAMATAN HARAU, 50 KOTA

Dira Herawati, Muhammad Husni, A Nick Koto Agam, Eza Ramadhani

PELATIHAN FOTOGRAFI PADA KEGIATAN EKSTRA KURIKULER DI SMKN 2 PADANGPANJANG

F. X Yatno Karyadi, Eriswan, Bari, Rahmat, Irham

PELATIHAN PEMBUATAN VIDEO DAN FOTO MAKRO MENGGUNAKAN TABLE-TOP STUDIO UNTUK SISWA SMA

Novina Yetri Fatrina, Ediantes, Putri Andam Dewi, Suri Handai Yani

PELATIHAN TEKNIK MEMBUAT RIAS EFEK UNTUK FILM FIKSI PADA SMK 2 PADANGPANJANG

Rosta Minawati, Heri Sasongko, Gilang Febriano, Vini Rusmana

PENGENALAN PRODUKSI FILM DOKUMENTER BAGI SISWA/ SISWI SEKOLAH MENEGAH ATAS

Hafif HR, Fahmi Marh, Ade Sulistiawan, Dino Ashari

PENERAPAN MULTI DISIPLIN SENI DALAM KEGIATAN DRUMBAND PADA EKSTRAKURIKULER SMA 3 PADANGPANJANG

Febri Yulika, Selvi kasman, Putri Khairina Masta

PENINGKATAN KOMPETENSI GURU MELALUI PELATIHAN PENULISAN KARYA TULIS ILMIAH

Darmansyah, Novesar Jamarun, Firdaus, Indra Arifin, Fitra Muhaddis

PELATIHAN INSTRUMEN MUSIK TRADISIONAL MINANGKABAU DI MAN 2 GUNUNG PADANGPANJANG 



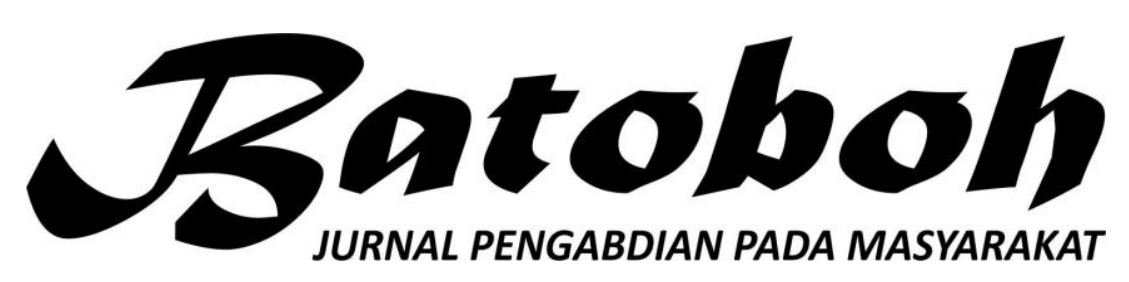

ISSN: 2548-5458 Volume 1, Nomor 2, Oktober 2016, hlm. 131-266

Terbit dua kali setahun pada bulan April dan Oktober. Pengelola Jumal Pengabdian pada Masyarakat merupakan subsistem LPPMPP Institut Seni Indonesia (ISI) Padangpanjang.

\author{
Pengarah \\ Rektor ISIPadangpanjang \\ Penanggung Jawab \\ Kepala Pusat Penerbitan ISI Padangpanjang \\ KetuaPenyunting \\ Andar Indra Sastra \\ Penyunting \\ Asril \\ Sahrul \\ RostaMinawati \\ Harissman \\ Pimpinan Redaksi \\ Saaduddin \\ Redaktur \\ Liza Asriana \\ Rori Dolayance \\ Tata Letak dan Desain Sampul \\ Yoni Sudiani \\ WebJurnal \\ Thegar Risky
}

Alamat Pengelola Jumal Batoboh:LPPMPP ISI Padangpanjang

Jalan Bahder Johan Padangpanjang 27128, Sumatera Barat; Telepon (0752) 82077 Fax. 82803;

e-mail; batoboh@gmail.com

Catatan. Isi/Materi jurnal adalah tanggung jawab Penulis.

Diterbitkan Oleh

Institut Seni Indonesia (ISI) Padangpanjang 


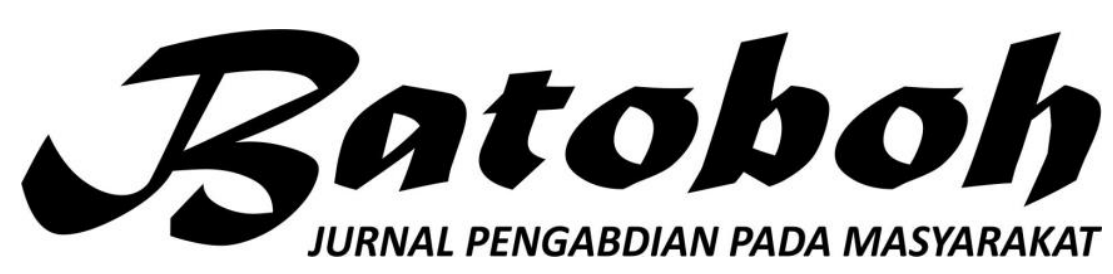

ISSN: 2548-5458 Volume 1, Nomor 2, Oktober 2016, hlm. 131-266

\section{DAFTAR ISI}

\begin{tabular}{|l|l|}
\hline \multicolumn{1}{|c|}{ PENULIS } & \multicolumn{1}{c}{ JUDUL } \\
\hline Yusfil, Zulkifli, Erlinda & $\begin{array}{l}\text { Penerapan Teknologi Seni Pada Sanggar Seni } \\
\text { Tradisional Di Kabupaten Pesisir Selatan Sumatera } \\
\text { Barat }\end{array}$ \\
Asril & $\begin{array}{l}\text { Pelatihan Lagu Siontong Tabang, Kureta Mandaki, } \\
\text { Dan Oyak Tabuik Pada Grup Gandang Tasa Anak- } \\
\text { Anak, Sanggar Anak Nagari Desa Sungai Pasak, } \\
\text { Kota Pariaman }\end{array}$ \\
$\begin{array}{l}\text { Nofrial, Wahyono, Riski } \\
\text { Rahmat Kurniawan Dan } \\
\text { Alek Hengki Ziora }\end{array}$ & $\begin{array}{l}\text { Pemanfaatan Serbuk Gergaji Menjadi Produk } \\
\text { Kerajinan Di Wan Perabot, Tarantang Kecamatan } \\
\text { Harau, 50 Kota }\end{array}$ \\
\hline
\end{tabular}

HALAMAN

Dira Herawati,

Muhammad Husni, A

Nick Koto Agam, Eza

Ramadhani

F. X Yatno Karyadi,

Pelatihan Fotografi Pada Kegiatan Ekstra

Kurikuler Di SMKN 2 Padangpanjang

131-144

$145-164$

Eriswan, Bari, Rahmat, Irham

Novina Yetri Fatrina, Ediantes, Putri Andam Dewi, Suri Handai Yani

Pelatihan Pembuatan Video Dan Foto Makro

190-200 Menggunakan Table-Top Studio Untuk Siswa SMA

Pelatihan Teknik Membuat Rias Efek Untuk Film 201-212 Fiksi Pada SMK 2 Padangpanjang

Rosta Minawati, Heri Sasongko, Gilang

Pengenalan Produksi Film Dokumenter Bagi $213-227$ Febriano, Vini Rusmana

Hafif HR, Fahmi Marh, Ade Sulistiawan, Dino Ashari Siswa/Siswi Sekolah Menegah Atas

$165-181$ 182-189

Febri Yulika, Selvi Kasman, Putri Khairina Masta

Darmansyah, Novesar Jamarun, Firdaus' Indra Arifin, Fitra Muhaddis

Penerapan Multi Disiplin Seni Dalam Kegiatan Drumband Pada Ekstrakurikuler SMA 3 Padangpanjang

Peningkatan Kompetensi Guru Melalui Pelatihan Penulisan Karya Tulis Ilmiah

Pelatihan Instrumen Musik Tradisional $256-266$ Minangkabau Di MAN 2 Gunung Padangpanjang

\footnotetext{
Peraturan Direktur Jenderal Pendidikan Tinggi Kementerian Pendidikan Kebudayaan Republik Indonesia Nomor 1 Tahun 2014 Tanggal Tentang Pedoman Akreditasi Terbitan Berkala Ilmiah. Jumal Batoboh Terbitan Vol. 1, April dan Oktober 2016 Memakaikan Pedoman Akreditasi Berkala Ilmiah Tersebut.
} 



\title{
PENINGKATAN KOMPETENSI GURU MELALUI PELATIHAN PENULISAN KARYA TULIS ILMIAH
}

\author{
Febri Yulika, Selvi kasman, Putri Khairina Masta \\ Prodi Seni Musik \\ Fakultas Seni Pertunjukan- ISI Padangpanjang. \\ Jl. Bahder Johan, Padangpanjang, Sumatra Barat \\ febri.isipp@gmail.com
}

\begin{abstract}
ABSTRAK
Pengabdian ini bertujuan untuk meningkatkan kemampuan guru-guru Sekolah Dasar Negeri Dharma Caraka dalam membuat tulisan ilmiah terkait laporan hasil penelitian tindakan kelas. Masalah yang dihadapi oleh para guru Sekolah Dasar Negeri Dharma Caraka adalah kurang termotivasi untuk membuat tulisan ilmiah disebabkan beberapa faktor, salah satunya adalah kurangnya pengetahuan dan kemampuan terkait kiat-kiat membuat tulisan ilmiah, dan kurangnya waktu karena kesibukan para guru melaksanakan tugas pokok menjalankan proses belajar mengajar. Metode yang dipergunakan adalah ceramah dan demonstrasi dalam menyampaikan materi pelatihan, serta pengaplikasian materi ke bentuk pelatihan membuat tulisan ilmiah yang diarahkan untuk membuat proposal dan laporan hasil penelitian tindakan kelas. Pengabdian ini diharapkan dapat memotivasi dan meningkatkan pengetahuan para guru tentang bagaimana cara membuat tulisan ilmiah, sehingga dapat memenuhi kebutuhan tulisan ilmiah terkait proposal, laporan hasil penelitian tindakan kelas dan makalah ilmiah. Pengetahuan dan kemampuan yang diperoleh guru pada pelatihan ini dapat meningkatkan kompetensi, kapasitas dan profesionalitas para guru sebagai pendidik.
\end{abstract}

Kata Kunci : tulisan ilmiah, penelitian tindakan kelas, kualitas dan profesionalitas guru. 


\section{PENDAHULUAN}

Pendidikan merupakan suatu kebutuhan yang mendasar bag kemajuan suatu bangsa. Pendidikan bersifat mutlak dan tidak dapat dipisahkan dari kehidupan masyarakat Salah satu masalah yang dihadapi bangsa Indonesia adalah rendahnya mutu pendidikan. Upaya peningkatan kualitas pendidikan merupakan salah satu fokus di dalam pembangunan Indonesia. Untuk mencapai kemajuan harus ada upaya sungguh-sungguh baik dari lembaga pemerintah dan ilmiah.

masyarakat pada umumnya. Sekolah sebagai lembaga pendidikan formal yang mendapat prioritas utama untuk menyelenggarakan proses belajar mengajar, mempunyai tanggung jawab yang besar. Namun keberhasilan tersebut dipengaruhi metode pembelajaran yang dipergunakan guru. Metode pembelajaran memberikan arah proses belajar mengajar sehingga menentukan keberhasilan dalam mencapai tujuan pembelajaran yang dimaksudkan.

Dalam menemukan metode keinginan menulis tulisan ilmiah dan pembelajaran para guru melakukan ini menjadi sebuah halangan untuk para penelitian terhadap permasalah yang guru dalam membuat tulisan ilmiah terjadi didalam proses pembelajaran. pembelajaran, dilakukan oleh para guru melalui penelitian tindakan kelas. Laporan hasil Penelitian tindakan kelas merupakan salah satu bentuk tulisan ilmiah yang dapat dilakukan oleh guru, untuk kepentingan membuat laporan penelitian tindakan kelas tersebut para guru harus memiliki kemampuan membuat laporan hasil penelitian dalam bentuk tulisan ilmiah yang memiliki kriteria dan aturan penulisan yang sesuai dengan kaidah-kaidah tulisan Permasalahan yang dihadapi para guru di Sekolah Dasar Negeri Dharma Caraka sebagai peserta kegiatan pengabdian dalam bentuk pelatihan membuat tulisan ilmiah adalah rendahnya motivasi para guru dalam menulis tulisan ilmiah terkait dengan membuat laporan hasil penelitian tindakan kelas yang mereka lakukan karena terbatasnya pengetahuan dan kemampuan para guru dalam membuat tulisan ilmiah. Kondisi ini menjadi penyebab rendahnya
Penelitian yang dilakukan terkait proses 
dalam bentuk laporan penelitian tindakan kelas yang telah dilakukan.

Kondisi ini secara tidak langsung membuat para guru kurang termotivasi membuat tulisan ilmiah, selain alasan kekurangan waktu karena para guru harus mengutamakan tugas pokok sebagai seorang pendidik, yang bertanggung jawab penuh terhadap kelancaran proses belajar mengajar. Inilah yang melatar belakangi dilakukannya pelatihan penulisan tulisan ilmiah dan sebagai salah satu cara yang dapat dilakukan terkait untuk meningkatkan kapasitas guru sebagai pendidik professional, dan keterkaitannya dalam rangka tercapainya tujuan peningkatan kualitas pendidikan anak didik.

Pelatihan penulisan karya tulis ilmiah dilakukan menggunakan metode ceramah dalam penyampaian materi pelatihan dan metode demonstrasi tentang bagaimana kiat-kiat membuat sebuah tulisan ilmiah yang tepat. Metode lainnya yang dilakukan adalah memotivasi para guru bahwa menulis tulisan ilmiah bukan pekerjaan yang sulit atau berat, sehingga tidak menjadi sebuah pekerjaan yang membebankan secara psikologis.
Hasil capaian dari kegiatan pelatihan ini, diharapkan para guru termotivasi dan mempunyai pemahaman tentang sebuah pengetahuan membuat tulisan ilmiah sehingga dapat menghasilkan sebuah tulisan ilmiah yang salah satunya berguna untuk kepentingan pelaporan penelitian tindakan kelas yang dilakukan, yang berdampak terhadap peningkatan professional sebagai guru.

\section{A. PELATIHAN PENULISAN KARYA TULIS ILMIAH}

Kegiatan pelatihan ini diawali dari penggalian motivasi dan hambatan yang dialami oleh para guru dalam membuat sebuah karya tulis ilmiah, khususnya terkait dengan laporan penelitian tindakan kelas. Penggalian aspek motivasi ini menjadi penting agar diketahui tingkat kesadaran dan keinginan para guru dalam membuat karya tulis sebagai tuntutan profesi dan sekaligus melihat korelasinya dengan kemampuan teknis dalam membuat karya tulis ilmiah. Hasil penggalian secara persuasif melalui metode pertanyaan tertutup kepada setiap guru, menyimpulkan beberapa hambatan psikologis guru dalam membuat karya 
tulis, diantaranya; merasa tidak bisa harus ditakuti apalagi dihindari, karena padahal belum mencoba, tidak percaya para guru memang tidak dapat diri pada kemampuan dan pengetahuan, menghindar kerena tuntutan untuk tidak ada keinginan untuk maju, pelaporan penelitian tindakan kelas atau tingginya rasa malu, takut, tidak kepentingan membuat karya tulis percaya diri bahwa pengetahuannya ilmiah untuk kenaikan pangkat atau sangat terbatas, kemampuan bahasanya membuat makalah untuk diseminarkan kurang baik, kurang mengetahui dan di lingkungan sekolah atau dinas menguasai pengetahuan untuk bidang pendidikan. Para guru dimotivasi keilmuan sendiri, tidak tahu apa yang bahwa menulis itu mudah dan syarat harus atau dapat ditulis untuk penulisan pertama untuk dapat menulis adalah ilmiah, tidak mampu untuk kemauan, dan mereka harus membahasakan gagasan pada penulisan memotivasi diri sendiri dengan cara karya ilmiah atau kurang memahami merefleksikan kebutuhan profesi model dan teknik penulisan karya sebagai seorang tenaga pendidik ilmiah, tidak memahami pentingnya professional. Sehingga kemudian baru berekspresi lewat karya tulis dan masih dapat masuk pada tahap berikutnya, terpaku pada budaya lisan, serta kurang yaitu transfer knowledge dan menghargai atau memahami pentingnya pengembangan kemampuan untuk penyebaran informasi lewat tulisan. meningkatkan profesionalitas sebagai

Berdasarkan hasil jawaban seorang guru.

dari kondisi psikologis peserta tersebut, kegiatan pelatihan mengawali dengan memberikan metode Achievment Motivation dalam bentuk membangkitkan semangat dan menanamkan pemahaman bahwa menulis itu pekerjaan yang menyenangkan, bukan sebuah pekerjaan yang sulit, walaupun tidak

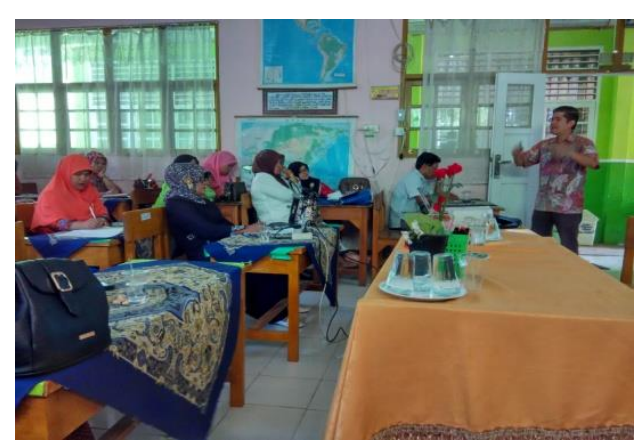

Gambar 1 Penggalian Motivasi Guru (Dokumentasi foto : Tim Pengabdian, 2016) sederhana tetapi bukan pekerjaan yang 


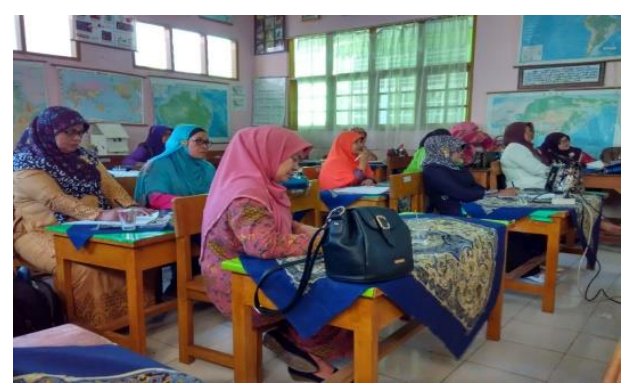

Gambar 2.

Penggalian Motivasi Guru (Dokumentasi Foto : Tim Pengabdian, 2016)

Setelah peserta pelatihan diberikan motivasi dalam membuat karya tulis ilmiah, maka kegiatan pelatihan dilanjutkan dengan pemberian materi terkait pengetahuan tentang tulisan ilmiah, konsep dasar tulisan ilmiah, serta bagaimana mengungkapkan ide dalam bahasa yang benar dan komunikatif. Pengetahuan dan kemampuan yang dikembangkan dalam materi ini berkaitan dengan isi tulisan, apa yang diuraikan dalam tulisan, dan kemampuan membahasakan apa yang ingin diungkapkan serta bagaimana cara mengungkapkan. Aspek isi dan bentuk adalah dua hal yang mendukung eksistensi sebuah karya tulis; keduanya saling terkait dan saling melengkapi. Tulisan dengan bahasa yang benar tetapi tidak dapat meyakinkan pembaca, berdampak terhadap minat orang untuk membacanya karena tidak memberi nilai tambah. Tulisan dengan ide yang bagus, orisinal, dan luas, tetapi jika bahasanya tidak benar akan kacau (bahasa menunjukan karakter penulis. Maka berlatih menulis karya ilmiah mesti melibatkan kedua unsur itu.

Sebagai langkah awal, pengabdi memberikan pemahaman umum kepada para guru tentang pengertian dan tujuan dari karya tulis ilmiah dan penelitian tindakan kelas (PTK). Arifbas (1992), menjelaskan bahwa "karya ilmiah adalah karangan ilmu pengetahuan yang menyajikan fakta dan ditulis menurut metode penulisan yang baik dan benar". Sementara menurut Rivai (2005), karangan ilmiah adalah suatu karangan atau tulisan yang diperoleh sesuai dengan sifat keilmuannya dan didasari oleh hasil pengamatan, peninjauan, penelitian dalam bidang tertentu, disusun menurut metode tertentu dengan sistematika penulisan yang bersantun bahasa dan isinya dapat di pertanggung jawabkan kebenarannya atau keilmuannya. Penelitian tindakan kelas berasal dari bahasa Inggris, yaitu Classrom Action Research, yang berarti penelitian dengan melakukan tindakan 
yang dilakukan oleh guru di dalam atas permasalahan yang dialami guru kelasnya sendiri melalui refleksi diri, dalam melaksanakan tugasnya seharidengan tujuan untuk memperbaiki hari. Pada pelaksanaannya, setiap kinerjanya sebagai guru, sehingga hasil masalah yang diungkap dan dicarikan belajar siswa menjadi menjadi jalan keluar haruslah masalah yang meningkat. Pertama kali penelitian benar-benar ada dan nyata dialami oleh tindakan kelas diperkenalkan oleh Kurt guru. Sedangkan menurut Arikunto Lewin pada tahun 1946, yang (2011) secara singkat PTK dapat selanjutnya dikembangkan oleh didefinisikan sebagai suatu bentuk Stephen Kemmis, Robin Mc Taggart, penelitian yang bersifat reflektif dengan John Elliot, Dave Ebbutt dan lainnya. melakukan tindakan-tindakan tertentu, Penelitian ini berorientasi pada untuk memperbaiki dan atau penerapan tindakan dengan tujuan meningkatkan praktek-praktek peningkatan mutu atau pemecahan pembelajaran di kelas secara lebih masalah pada sekelompok subyek yang profesional. Oleh karena itu PTK diteliti dan mengamati tingkat terkait erat dengan persoalan praktek keberhasilan atau akibat tindakannya, pembelajaran sehari-hari yang dialami untuk kemudian diberikan tindakan guru.

lanjutan yang bersifat penyempurnaan tindakan atau penyesuaian dengan kondisi dan situasi sehingga diperoleh hasil yang lebih baik.

Kunandar (2008) menyatakan bahwa yang dimaksud dengan penelitian tindakan kelas (PTK) adalah penelitian praktis, bertujuan untuk memperbaiki kekurangan-kekurangan dalam pembelajaran di kelas dengan cara melakukan tindakan-tindakan. berkualitas dalam proses sehingga hasil Upaya tindakan untuk perbaikan belajarpun menjadi lebih baik. Dari dimaksudkan sebagai pencarian jawab beberapa definisi seperti yang telah
PTK merupakan siasat guru dalam mengaplikasikan pembelajaran dengan berkaca pada pengalamnya sendiri atau dengan perbandingan dari guru lain. Menurut Bahri (2012:8) penelitian tindakan kelas merupakan sebuah kegiatan yang dilaksanakan untuk mengamati kejadian-kejadian dalam kelas untuk memperbaiki praktek dalam pembelajaran agar lebih beberapa definisi seperti yang telah 
dikemukakan, maka ciri utama dari penelitian tindakan adalah adanya intervensi atau perlakuan tertentu untuk perbaikan kinerja dalam dunia nyata. Elliot (1982) mengatakan, "The fundamental aim of action research is to improve practice rather than toproduce knowledge" (Sanjaya, 2011:25).

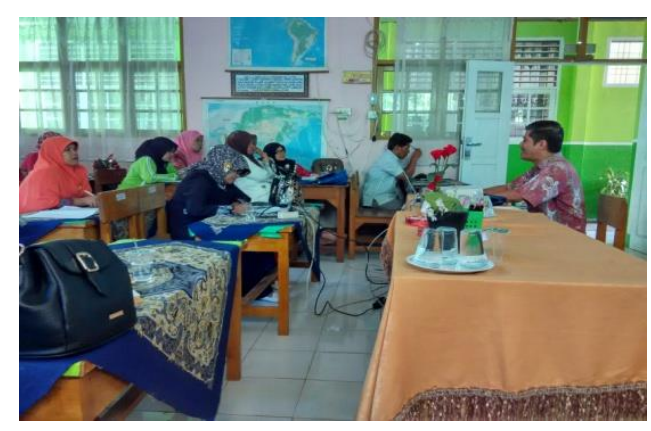

Gambar 3.

Penjelasan Umum Materi Pelatihan (Dokumentasi Foto : Tim Pengabdian, 2016)

Setelah peserta memahami pengertian umum tentang karya tulis ilmiah dan penelitian tindakan kelas, tahapan berikutnya para peserta pelatihan diberi materi bagaimana menyiapkan proposal penelitian tindakan kelas, mulai dari judul, abstrak, pendahuluan, kajian pustaka, metode penelitian, perumusan masalah, tujuan penelitian, manfaat penelitian, setting penelitian, subjek penelitian, sumber data, teknik dan alat pengumpulan data, validasi data, analisis data, indikator kinerja serta prosedur penelitian. Materi pelatihan difokuskan pada aspek teknis dan tahapan-tahapan pembuatan karya tulis ilmiah, dengan ringkasan materi sebagai berikut :

\section{a. Pemilihan Topik}

Topik adalah pokok pembicaraan dalam keseluruhan tulisan yang digarap. Topik harus ditentukan sebelum mulai menulis sebab aktivitas menulis tidak mungkin dilakukan tanpa topik. Oleh karena itu, kegiatan pertama yang harus dilakukan pada tahap pra penulisan ialah memilih topik. Di dalam memilih topik karya ilmiah harus dipertimbangkan hal-hal berikut ini :

1) Topik harus bermanfaat dan layak dibahas. Bermanfaat berarti bahwa pembahasan topik itu akan memberi sumbangan bagi pengembangan ilmu dan profesi. Layak dibahas berarti bahwa topik itu memang memerlukan pembahasan dan sesuai dengan bidang yang ditekuni.

2) Topik cukup menarik, terutama bagi penulis. Topik yang demikian dapat memotivasi 
penulis berusaha secara kontinu mencari data yang berguna dalam membahas masalah yang dihadapi dan memotivasi penulis menyelesaikan masalah karya ilmiahnya secara baik. Bagi pembaca, topik yang demikian mengandung minat untuk membacanya.

3) Topik dikenal baik. Ini berarti topik yang dipilih, harus topik yang dikuasai atau diketahui penulis sendiri. Sekurangkurangnya prinsip-prinsip ilmiahnya dikuasai oleh penulis.

4) Bahan yang diperlukan untuk pembicaraan topik itu, dapat diperoleh dan cukup memadai. Bahan penulisan adalah semua informasi atau data yang relevan digunakan untuk mencapai tujuan penulisan. Data itu mungkin merupakan teori, contoh - contoh, rincian atau detail, perbandingan, fakta, hubungan sebab - akibat, pengujian dan pembuktian, angka - angka, kutipan, gagasan, dan sebagainya yang dapat membantu penulis dalam mengembangkan tema. Sumber utama bahan penulisan adalah pengalaman dan inferensi dari pengalaman.

5) Tidak terlalu luas dan tidak terlalu sempit. Topik yang terlalu luas tidak memberi kesempatan kepada penulis untuk membahasnya secara mendalam. Apalagi jika panjang karya ilmiah dibatasi (misalnya oleh panitia seminar). Sebaliknya apabila topik terlalu sempit, maka sifatnya terlalu khusus, tidak dapat digeneralisasi, sehingaa tidak banyak gunanya bagi pengembangan ilmu.

6) Menentukan topik sesuai dengan kriteria di atas dapat dilakukan dengan cara memperbanyak bahan bacaan, berdiskusi dengan sejawat atau seminar, sehingga akan muncul ide awal untuk sebuah tulisan ilmiah. Ide yang sudah diperoleh harus dikembangkan menjadi sebuah tulisan, menulis apa saja yang dipikirkan dan yang ingin ditulis dengan berani tanpa takut merasa salah, walau bentuk tulisan belum berwujud, 
tidak terkait, belum tertata, maka tahap berikutnya baru dicoba dikembangkan menjadi sebuah outline. Outline merupakan kerangka karangan, garis besar, yang berisikan kerangka topik dan sub topik yang akan dikembangkan menjadi sebuah tulisan yang lengkap. Dengan membaca outline, pembaca sudah dapat membayangkan isi karangan secara keseluruhan karena outline adalah daftar isi sebuah karya tulis. Pengembangan outline menjadi tulisan yang utuh dilakukan secara runut, dan menggunakan bahasa yang benar sesuai dengan kaidah penulisan ilmiah.

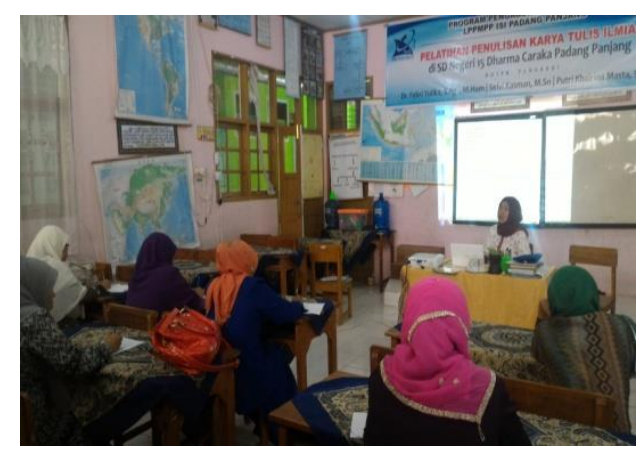

Gambar 4.

Penjelasan Materi PTK (Dokumentasi Foto : Tim Pengabdian, 2016)

\section{b. Penentuan Judul}

Setelah diperoleh topik yang relevan, topik tersebut dinyatakan dalam suatu judul karya ilmiah. Topik berbeda dengan judul. Topik adalah pokok pembicaraan dalam keseluruhan karya ilmiah yang digarap, sedangkan judul adalah nama dalam suatu karya ilmiah. Pernyataan topik mungkin saja sama dengan judul tetapi mungkin juga tidak. Dalam karya ilmiah, judul harus tepat menunjukkan topiknya. Penentuan judul harus dipikirkan secara serius dengan mengingat beberapa syarat berikut :

1) Judul harus sesuai dengan topik atau isi karya ilmiah beserta jangkauannya.

2) Judul sebaiknya dinyatakan dalam bentuk frase benda bukan dalam bentuk kalimat.

3) Judul karya ilmiah diusahakan sesingkat mungkin.

4) Judul karya ilmiah harus dinyatakan secara jelas. Artinya judul itu tidak dinyatakan dalam kata kiasan atau tidak mengandung kata yang mendukung makna ganda. 


\section{c. Perumusan Tema}

Meskipun topik yang terbatas telah diperoleh, penulis belum bisa mulai menulis. Penulis harus menetapkan maksud dan tujuannya menggarap topik tadi. Tujuannya adalah mengarahkan perkembangan tulisan. Setelah itu, penulis membuat rumusan mengenai masalah dan tujuan yang dicapai dengan topik tadi. Rumusan itu dinamakan tema, untuk memenuhi keperluan penyusunan sebuah kerangka tulisan ilmiah, rumusan tema harus berbentuk tulisan ilmiah, rumusan tema harus berbentuk kalimat. Rumusan singkat yang mengandung tema dasar sebuah karya ilmiah disebut tesis. Ini berarti bahwa ada satu gagasan sentral yang menonjol. Apabila tulisan itu tidak menonjolkan suatu gagasan utama, maka yang ingin disampaikan, dapat dinyatakan dalam bentuk penjelasan singkat. Rumusan singkat yang tidak menekankan tema dasar disebut pengungkapan maksud.

\section{d. Mengindentifikasi, Menganalisis,} dan Merumuskan Masalah PTK.

Penelitian tindakan kelas berawal dari kepekaan guru terhadap permasalahan yang muncul dikelasnya, sehingga alasan untuk memperbaiki proses pembelajaran menjadi latar belakang pentingnya penelitian tindakan kelas dilakukan. Masalah yang sudah ditetapkan harus dianalisis; masalah harus faktual, harus dapat dicari alternatif penyelesaiannya, serta memiliki nilai strategis bagi peningkatan atau perbaikan proses dan hasil pembelajaran.

Setelah memperoleh permasalahan-permasalahan melalui proses identifikasi tersebut, maka guru peneliti selanjutnya melakukan analisis terhadap masalah-masalah tersebut untuk menentukan urgensi penyelesaiannya. Dalam hubungan ini, akan ditemukan permasalahan yang sangat mendesak untuk diatasi seperti misalnya penguasaan materi pelajaran pada topik pewarisan sifat, sikap siswa dalam berdiskusi atau sikap siswa dalam melakukan percobaan. Permasalahan tersebut jika tidak segera diselesaikan akan 
menimbulkan dampak negatif yang besar (tidak tercapainya kriteria ketuntasan minimal, kurang kerjasama dalam diskusi dan eksperimen). Walaupun demikian, tidak semua permasalahan dalam pembelajaran yang dapat diatasi dengan PTK (seperti kesalahankesalahan faktual dan/atau konseptual yang terdapat dalam buku paket).

Setelah mengidentifikasi dan menganalisisnya, maka guru selanjutnya perlu merumuskan permasalahan secara lebih jelas, spesifik, dan operasional. Perumusan masalah yang jelas akan membuka peluang bagi guru untuk menetapkan tindakan perbaikan yang perlu dilakukannya, jenis data yang perlu dikumpulkan, termasuk prosedur pengumpulan data serta cara menginterpretasikannya. Disamping itu, penetapan tindakan perbaikan yang akan dicobakan itu juga memberikan arahan kepada guru untuk melakukan berbagai persiapan. Termasuk yang berbentuk latihan guna meningkatkan keterampilan untuk melakukan tindakan perbaikan yangdi maksud.
Perumusan permasalahan yang lebih tajam itu dapat dilakukan diagnosis kemungkinan-kemungkinan penyebab yang lebih cermat, sehingga terbuka peluang untuk menjajaki pertanyaan alternatif tindakan perbaikan yang diperlukan.

Pembahasan lainnya yang tidak kalah penting yaitu penulisan daftar pustaka, cara merujuk tulisan ilmiah, format dan sistematika penulisan yang harus disesuaikan dengan ketentuan yang ditentukan oleh jurnal atau majalah atau untuk keperluan tertentu dari penulisan karya tulis ilmiah tersebut. Selain itu juga dijelaskan empat aspek yang menjadi karakteristik dan penilaian utama dari sebuah karya tulis, yaitu :

1. Struktur sajian;

Struktur sajian karya ilmiah sangat ketat, biasanya terdiri dari bagian awal (pendahuluan), bagian inti (pokok pembahasan), dan bagian penutup. Bagian awal merupakan pengantar ke bagian inti, sedangkan inti merupakan sajian gagasan pokok yang ingin disampaikan yang dapat terdiri dari beberapa bab atau subtopik. Bagian penutup merupakan simpulan 
pokok pembahasan serta bagaimana mempersiapkan sebuah rekomendasi penulis tentang tindak presentasi, tentang bagaimana lanjut gagasan tersebut.

menyiapkan power point yang

2. Komponen dan substansi

Komponen karya ilmiah bervariasi representative, sebagai alat bantu untuk sesuai dengan jenisnya, namun mempresentasikan tulisan ilmiah. semua karya ilmiah mengandung mencapai tujuan ditentukan oleh pendahuluan, bagian inti, penutup, beberapa kriteria, diantaranya; dan daftar pustaka. Artikel ilmiah kemampuan menarik perhatian peserta, yang dimuat dalam jurnal isi presentasi disajikan secara mempersyaratkan adanya abstrak. sistematis, penjelasan disesuaikan

3. Sikap penulis

Sikap penulis dalam karya ilmiah adalah objektif, yang disampaikan dengan menggunakan gaya bahasa impersPonal, dengan banyak menggunakan bentuk pasif, tanpa menggunakan kata ganti orang pertama atau kedua.

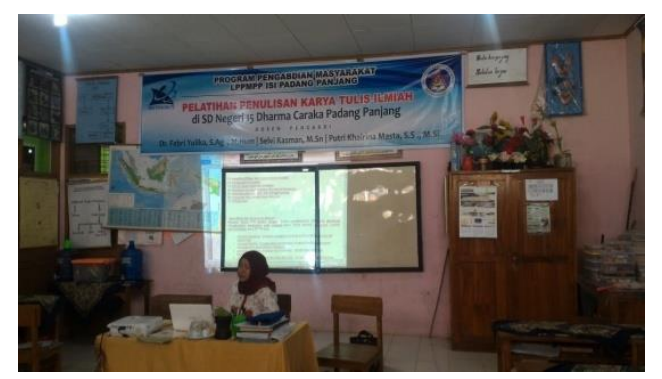

Gambar 5.

Pemberian Materi PTK

(Dokumentasi Foto : Tim Pengabdian, 2016)

Materi pelatihan diakhiri dengan keterampilan para guru dalam hal teknik presentasi yang efektif. Pada tahapan ini peserta diberi materi dengan tingkat nalar pendengar, memberikan contoh dan argumen yang kuat serta menggunakan media atau alat bantu. Media dan alat bantu yang digunakan dalam presentasi sebaiknya efektif dan efisien, seperti media yang mudah, murah, praktis, aman, kesesuaian bahan dengan metode penyajian, kesesuaian media dengan karakteristik peserta, tepat, daya tahan (kuat), dan tersedia.

Setelah semua materi secara konsep dan teori selesai dibahas, maka untuk meningkatkan kemampuan menulis, para guru harus mengaplikasikan materi yang sudah diperoleh melalui praktek membuat tulisan ilmiah, yang dimulai dari tahap yang paling awal yaitu para guru harus menentukan permasalah yang akan 
diangkat menjadi sebuah proposal sebagai awal dari sebuah penelitian yang akan dilakukan. Praktek kerja pembuatan proposal merupakan bentuk implementasi dari materi yang sudah diberikan, dan diharapkan peserta mampu membuat tulisan ilmiah sesuai dengan kaidah-kaidah yang baik.

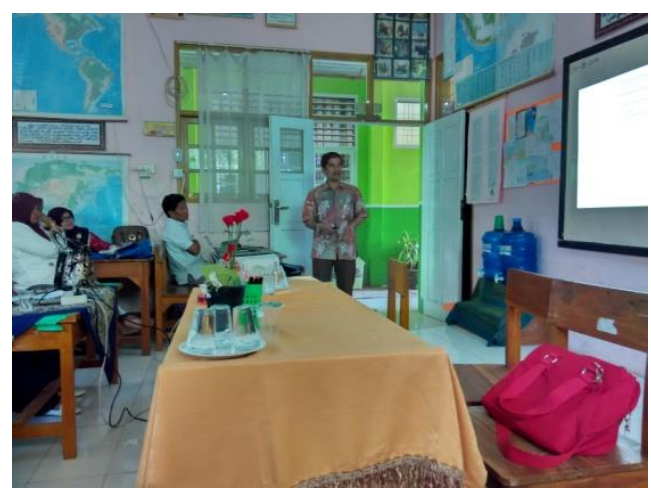

Gambar 6 .

Penjelasan Praktek Presentasi PKT

(Dokumentasi Foto : Tim Pengabdian, 2016)

\section{KESIMPULAN}

Hasil capaian dari kegiatan pelatihan pembuatan karya tulis ilmiah ini adalah; munculnya kesadaran para guru bahwa kemampuan menulis itu merupakan hal yang penting dan tidak merupakan sebuah pekerjaan yang membebani, dengan indikator kehadiran peserta yang cukup antusias serta peserta merespon dengan cukup baik. Peserta memahami materi terkait dengan pelatihan yang diarahkan pada karya tulis yang sesuai dengan penelitian tindakan kelas. Indikator penilaian yang digunakan tim pengabdi adalah para peserta pelatihan dengan mudah dapat mengindentifikasi persoalan yang dapat diangkat menjadi sebuah permasalahan untuk dijadikan sebuah penelitian tindakan kelas, sesuai dengan kaidah-kaidah karya tulis ilmiah. Para peserta pelatihan dapat menghasilkan sebuah tulisan ilmiah sekurangnya pada taraf memiliki kemampuan membuat sebuah proposal penelitian sebagai implementasi dari materi pelatihan yang sudah diberikan, serta memiliki kemampuan untuk mempresentasikan hasil tulisan ilmiah, membuat power point, dan mampu mengelola manajemen diri sehingga mampu tampil secara maksimal dengan menggunakan teknik presentasi yang efektif, menggunakan bahasa yang jelas serta mudah dipahami oleh audiens.

\section{KEPUSTAKAAN}

Arifbas, 1992, Pedoman Penyusunan karya Tulis Ilmiah,edisi pertama, Surabaya, Universitas Surabaya Press.

Arikunto, Suharsimi, dkk., 2011, Penelitian Tindakan Kelas. Jakarta: Bumi Aksara. 
Bahri, Aliem. 2012, "Penelitian Rivai, 2005, Pegangan Gaya Menulis, Tindakan Kelas". Makassar : Penyuntingan, dan Universitas Muhammadiyah Penerbitan, Karya Ilmiah, Makassar.

Yogyakarta, UGM Press.

Kunandar, 2008, Langkah Mudah Sanjaya, Wina, 2011, Penelitian Penelitian Tindakan Kelas Sebagai Pengembangan Tindakan Kelas, Jakarta : Profesi Guru, Jakarta: PT Kencana Prenada Media Raja Grafindo Persada. 
FILOSOFI "BATOBOH": Dalam masyarakat Minangkabau upacara-upacara yang dilakukan sebelum mendirikan bangunan baik Rumah Gadang maupun Balairung (Balai Adat) serta bangunan lainnya yang dikenal dengan beberapa upacara yang disebut dengan batoboh. Batoboh berasal dari kata Taboh yang artinya menebang atau mengambil sesuatu, jadi dengan mengambil kayu dihutan sebagai bahan utama dalam membangun rumah dan bangunan lainnya. Upacara Batoboh ini sangat bermanfaat bagi masyarakat Minangkabau yaitu dapat meningkatkan Gotong-Royong dan solidaritas antar sesama suku Minangkabau karena memberi kesempatan kepada kerabat-kerabat untuk terlibat dalam pembangunan rumah serta bangunan lain.

Alamat Redaksi: LPPMPP ISI Padangpanjang Jalan Bahder Johan Padangpanjang 27128 Sumatera Barat Telp. (0752) 485466, Fax.(0752) 82803 e-mail: batoboh@gmail.com

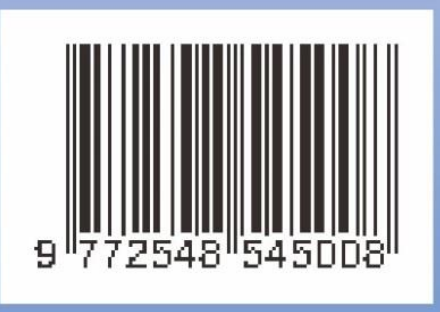

